Грицевич, Юрій. «Лемківська лексика у фольклорних записах Ореста Гижі». Лінгвостилістичні студії, вип. 10, 2019, с. 29-44.

Hrytsevych, Yurii. "Lexical Units of Lemky Dialect in the Folklore Records of Orest Hyzha”. Linguostylistic Studies, iss. 10, 2019, pp. 29-44.

УдК 811.161.2'28'373.4(477.83/.87):398

https://doi.org/10.29038/2413-0923-2019-10-29-44

\title{
ЛЕМКІВСЬКА ЛЕКСИКА У ФОЛЬКЛОРНИХ ЗАПИСАХ ОРЕСТА ГИЖІ
}

\author{
Юрій Грицевич \\ Східноєвропейський національний університет імені Лесі Українки, \\ Луцьк, Україна
}

Вивчення говірок, які внаслідок політичних процесів утратили цілісність ареалу, набуває особливого значення. У середині XX століття (1944 - 1947 рр.) лемки, західна група українського народу, перенесли етноцид - насильницьке виселення з рідних земель на територію України та на північно-західні землі Польщі. Стаття присвячена аналізу діалектної лексики в текстах народних пісень, записаних Орестом Гижею від лемків-переселенців. 3'ясовано семантику виявлених діалектних іменників, дієслів, прикметників, прислівників, службових частин мови. Визначено найбільш репрезентативні семантичні групи досліджуваних лексем.

Ключові слова: діалектна лексика, фольклор, лемки, лемківський діалект, південно-західне наріччя, номен, лексико-семантична група.

Hrytsevych Yurii. Lexical Units of Lemky Dialect in the Folklore Records of Orest Hyzha. Theriches of the Ukrainian dialectal lexicon provide multifaceted opportunities for the study of its composition structure, the system of organization, features of functioning and its areal specifics. One of the most important tasks of modern Ukrainian dialectology is the systemic study of the vocabulary throughout the ethnic-speaking territory. In this context, the study of the dialects that have lost the integrity of areal as a result of political processes becomes a topical scientific issue. In the middle of the twentieth century (1944-1947), the Western ethnic group of the Ukrainians, Lemki, experienced the greatest tragedy in history forced eviction from their native lands to the territory of the Ukrainian SSR and the northwestern lands of Poland.

In 1945 a doctor-dentist, musician-amateur, a well-known collector of Lemky folk songs Orest Hyzha was deported to Ukraine. His collection «Ukrainian Folk Songs from Lemkivshchyna» includes 300 song samples, recorded by 0. Hyzha since1933.The article analyzes the dialectal lexical units revealed in the folk texts of Lemky-migrants. The materials of the case study allowed to distinguish ten lexical-semantic groups: 1) verbs (words for the designation of physiological, mental processes and states, verbs of motion and displacement, actions that cause changes in the object, speech processes); 2) lexicon to indicate the names of buildings, agricultural structures, their parts and other related objects; 3) vocabulary for designating persons by the kind of their activity or employment; 4) vocabulary for the designation of family members, families, family ties, the names of persons by their matrimonial or age status; 5) adjectives with the positive ( negative connotation; 6) the names of the garments and footwear; 7) the names of foods, drinks, kitchen utensils; 8) the

(C) Грицевич Ю., Східноєвропейський національний університет імені Лесі Українки, 2019.

Це стаття відкритого доступу на умовах CC BY-NC 4.0 
names of the household objects; 9) vocabulary for designation of the realities of the animalplant world (flora and fauna); 10) appellative names for the geographical concepts. In the lyrics, there are also a lot of borrowings from other languages, especially from the neighboring countries (Polish, Slovak and German). The register of dialectical vocabulary reflects the local characteristic features of the carriers of the southern-western Lemky dialect. The dialectal core of the folk songs language of the south-west dialect proves the necessity of involving multi-ethnic folklore texts into the dialectological research.

Key words: dialectical vocabulary, folklore, Lemki, the dialect of Lemki, Southwestern dialect, nomen, lexical-semantic group.

Вступ. Системне вивчення лексики на всій етномовній території одне з першочергових завдань сучасної української діалектології. У цьому контексті особливого значення набуває дослідження говірок, які внаслідок політичних процесів утратили цілісність ареалу. Своєрідне місце на діалектній карті української мови посідають лемківські говірки, долю яких у середині XX століття вирішила сумнозвісна операція під кодовою назвою «Вісла» - завершальний етап депортацій, який полягав у примусовому виселенні українців з Лемківщини, Надсяння, Підляшшя і Холмщини на західні та північні землі Польської держави, що до 1945 року належали Німеччині. 9 вересня 1944 року у Любліні була підписана «Угода між урядом Української Радянської Соціалістичної Республіки і Польським Комітетом Національного визволення про евакуацію українського населення 3 території Польщі і польських громадян 3 території УРСР» (Український інститут). Відповідно до цієї угоди депортовано понад 500 тис. осіб із споконвічних земель Лемківщини, Холмщини, Надсяння та Підляшшя. Як відзначають історики, упродовж 1945-1947 років лемківське населення Жешувського (Ряшівського), Люблінського та Краківського воєводств ешелонами вивозили у західний та східний регіони УРСР. Тих, хто відмовлявся «добровільно» залишити рідні землі, було виселено на так звані «Ziemie Odzyskane» - приморські області Польщі (Наконечний). На цих колишніх німецьких територіях, що після війни відійшли до Польщі, лемків розселили по 3-5 родин в одній місцевості. Частка населення України щодо польського в кластері (муніципалітеті) немогла перевищувати 10 відсотків. До кінця 1947 рокув місця, звідки було депортовано українське населення, переселено близько 14 тисяч осіб польської національності (Орловська; Український інститут; Халюк). Переселення українців з їхніх етнічних земель мало проводитися на добровільних засадах, однак відбувалось під адміністративним тиском органів влади примусово і з застосуванням сили, що набуло характеру етноциду.

На території України лемків розселили в Тернопільській, Львівській, Волинській, Івано-Франківській, Рівненській, Донецькій, Харківській, Дніпропетровській, Запорізькій, Одеській, Кіровоградській, Миколаївській, Херсонській, Полтавській, Сумській та ін. областях. Депортація призвела до руйнування осілості та надзвичайно ускладнила процес збереження 
культурних надбань лемків, зокрема фольклору. У лютому 2007 року Президент Польщі Лех Качинський і Президент України Віктор Ющенко в спільній заяві засудили акцію «Вісла». 5 квітня 2007 року Віктор Ющенко підписав Указ № 274 «Про заходи до 60-х роковин операції „Вісла”, де примусове переселення етнічних українців названо страшними подіями в історії України.

Лемківський діалект належить до карпатської діалектної групи південно-західного наріччя української мови, на сході межує з бойківським говором і закарпатським говором, на півдні й заході - зі словацькими, на півночі - з польськими говорами. Однією з істотних ознак лемківського говору є сталий (слабо динамічний) наголос - на другому від кінця слова складі, за винятком східних говірок з рухомим (динамічним) наголосом. Так, А. Залеський підкреслював: «Лемківський говір має і такі особливості, що витворилися в ньому спонтанно, незалежно від інших мов, наприклад, ствердіння приголосних у кінці багатьох слів: кін «кінь», оген «вогонь», cмерт «смерть»; частий перехід прийменника (і префікса) в перед приголосним в 2 або $\boldsymbol{x}$ : Ілежит г боІлоті, Іпішов г дыругый бік, сІтойіт х коІморі, гlдовец, хlnеред та ін. <...> По суті лише одномісний наголос i ствердіння приголосних типу кін, $\boldsymbol{c м e p m ~} \epsilon$ суто лемківськими рисами» (71). Про карпатські говори, до яких належать також лемківські, Ф. Жилко писав 1958 року: «Карпатські говірки мають свої особливості у лексичному складі. Це виявляється в збереженні деяких давніх (архаїчних) слів, у наявності місцевих слів, що зустрічаються у вівчарстві, скотарстві, різних ремеслах, назвах рослин та ін. Зокрема в цих говірках помітні лексичні запозичення з румунської, угорської, турецької, словацької та польської мов» (125).

Спеціальне дослідження лемківського говору започаткував I. Верхратський. У праці «Про говір галицьких лемків» цей український лексиколог кінця XIX - першої половини XX століття та, за словами I. Франка, «кращий знаток української діялектології», пише: «В Галичині назва Лемки була первістно прозивкою, котра вишла вперше мабуть від сумежних Бойків. Оба тоті племена рускі взаїмно передразнювали ся: Бойки називали своїх руских сусідів від частиці лем місто в Бойківщині вживаного слівця лише «Лемками»; Лемки же своїх руских сусідів від частиці бойє дразнили «Бойками». Тому то Лемки зарівно як і Бойки ще і тепер дуже нерадо чують від сусідів тоті прозивки і рішучо від тих назв відпекують ся. Коли Лемка поспитати: «Ви лемки?», - то відповідає він видимо обиджений з неохотою: «Мы Руснакы; маме язык выкладный; Лемкы то може дес дале, там медже Бойкы». <...> Зайшлих з Угорщини Руснаків Бойки не злюбили і докорювали їм одмінною їх бесідою, передовсім же незвичайною на Руси частицею «лем», чим викликали і із сторони Лемків подібне докорюваннє задля частиці бойе та прозивку «Бойка». Розуміє ся, що з часом поволи устає тото неприязне відношенє обо впрочім так близьких собі руских племен і надіяти ся з поступом 
просьвіти устане вскорі зовсім, а тілько полишають ся назви, до котрих і 3 люду ніхто вже не буде прив'язувати якоїсь обидливої думки» (Верхратський 1-2). Роботи І. Зілинського, І. Керницького, М. Лесіва, П. Пиртея, Я. Рігера, 3. Штібера послужили базою для подальшого вивчення лемківського говору, дали поштовх до нових пошуків. На сучасному етапі спостерігаємо особливе зацікавлення науковців лемківською тематикою. Зокрема, це відображено у виголошених та опублікованих доповідях Міжнародної наукової конференції «Лемківський діалект у загальноукраїнському контексті» (Studia methodologica), яка відбулася у квітні 2009 року в Тернопільському національному педагогічному університеті імені Володимира Гнатюка.

Мета статті - дослідити лексико-семантичні групи діалектної лексики в текстах народних пісень, записаних О.Гижею від лемківпереселенців. Поставлена мета передбачає розв'язання таких завдань: 1) виявити лексичні діалектизми у фольклорному матеріалі; 2) визначити семантику зафіксованих слів; 3) здійснити класифікацію діалектних номенів за типом семантики; 4) встановити генезу досліджуваної лексики.

Методи дослідження. Основний метод узагальнення спостережень дескриптивний, за допомогою якого систематизовано та експліковано фольклорний матеріал. Частково використано прийоми внутрішньої та зовнішньої реконструкцій (залучення мовних елементів різної давності та матеріалу споріднених мов, щоб з'ясувати походження лемківських діалектизмів).

Виклад основного матеріалу. Орест Гижа народився 15 жовтня 1913 року в с. Висова Горлицького повіту (нині Республіка Польща). Після закінчення місцевої гімназії вступив до Варшавської стоматологічної академії. 1912 року у Висовій перебував Філарет Колесса, під безпосереднім впливом якого почав записувати пісні Орест Гижа. 1945 року О. Гижу депортовано в Україну (м. Бережани Тернопільської області), де він працював лікарем-стоматологом у районній лікарні. Академік М. Мушинка пригадує: «У 1972 р. Орест Гижа надіслав мені свої «Українські народні пісні з Лемківщини», видані під загальною редакцією Софії Грици київським видавництвом «Музична Україна». Я був захоплений прекрасно оформленою книжкою (художник Й. Шелест), яка містила тексти і мелодії 312 пісень, записаних від 32 співачок і співаків із 12 лемківських сіл Польщі. Записи було зроблено дуже старанно, зі збереженням діалектних особливостей та мелодійних нюансів. Упорядник присвятив збірку «Світлій пам'яті академіка Ф.М. Колесси». Пісні були упорядковані за жанрово-тематичним принципом, діалектні слова пояснені в окремому словнику» (Українські народні пісні 8).

Серед лемківських лексичних діалектизмів у фольклорних записах 0. Гижі виділяємо назви осіб за різними ознаками: а) особові найменування за ознакою спорідненості та свояцтва: няньо, нянюсьо - тато, пор.: «Ходила Марися на иментар по зіля, просила нянюся: подте на весіля!» (Українські 
народні пісні 42); «А як же би я з вами сідала, іщи-м няньови не дякувала» (Українські народні пісні 47); «Ішла за ньом Ганусенька і там она заснула, ішов за ньом єй нянюсьо, але она не чула» (Украӥнські народні пісні 58), «Мала-м няня заверуху, теля, теля, теля-ля, окрутив мя до кожуха» (Українські народні пісні 204) - пор. слц. Ňaňa «тітка; [татко]», ňаňо «тато; татко» (Етимологічний словник 4: 123); цера- дочка, пор.: «Чекай, дівча, до вечора, буде хлопещь або цера» (Українські народні пісні 265) - запозичення 3 польської мови, пор. п. córka та його пестливі деривати córuś, córunia (Етимологічний словник 6: 267); б) назви осіб за професійною діяльністю: гудак - музикант, пор.: «Там єй весіля стояло, десят гудаків, шість пахоляків ї грало» (Українські народні пісні 39), «Заграй мі, гудачку, на тонку струночку, жеби-м витанцював ей, мою фраїрочку» (Українські народні пісні 195); жовнір - солдат, пор.: «А там долов, під липиною стоїт жовнір з дівчиною» (Українські народні пісні 255) - запозичення 3 польської мови; п. żołnierz < żołdnierz, як і ч. žoldnéř, слц. žoldniér, походить від свн. soldenære «найманець, найманий солдат», яке зводиться до фр. ст. solde «плата» (від назви монети, що походить від лат. (nummus) solidus «тверда (монета)») (Етимологічний словник 2: 202); в) назви осіб за віковим статусом особи: челядь - молодь, пор.: «Ой на Яна на Янонька горіла нам собітонька, як горіла, так палала, аж ся челяд чудувала» (Українські народні пісні 25) - псл. с̌еl'adb, утворене від *̌̌elь (пов'язаного з čelo, укр. чоло, *čelověkъ) за допомогою збірного суфікса -jadb; далі зіставляється з коліно, покоління (Етимологічний словник 6: 293); шугай хлопець, пор.: «Світив би місячок, хмари му не дают, взяв би шугай дівча, люди огваряют» (Українські народні пісні 82), «До коний, шугай, до коний, не до дівчини, не до ней, до коний, шугай, з уздечком, не до дівчини з хустечком» (Українські народні пісні 170) - запозичення зі словацької мови; слц. šиһaj «хлопець, юнак» походить від уг. suhanc «підліток; парубок; хлопчак; вуличний хлопчисько», що виникло 3 давнішої форми suchancár «швейцарець», запозиченої з німецької мови (Етимологічний словник 6: 485); г) назви осіб за інтимними стосунками: фраїрове - хлопцізалицяльники, коханці, пор.: «Ей, оставайте здрави, мої сусідове, ей не зобудят юж вас мої фраӥрове» (Украӥнські народні пісні 50); фраӥр коханий; коханець, пор.: «Мала я фбраїра гребеняря, што робив гребені до цисаря, тоти гребені добре чешут, висівски парібци вшитки брешут» (Українські народні пісні 175) - запозичення з німецької мови, можливо, через польське посередництво; н. Freier «наречений», freien «свататися, одружуватися» (Етимологічний словник 6: 126); г) назви осіб комплексної семантичної характеристики: газдиня - господиня, пор.: «Возьми мя, Янчик, возьми мя, буде з мя добра газдиня, буду я рано вставала, коничкім воду давала» (Українські народні пісні 170) - запозичення з угорської мови; уг. gazda «господар», у свою чергу, походить із слов'янських мов (< слов. gospoda) (Етимологічний словник 1:451); д) обрядові назви осіб: хресня дитина, хрестини якої святкують, пор.: «Ани тото хресня веселе не буде, як 
му хресна мати співати не буде» (Українські народні пісні 69) - через посередництво старослов'янської мови запозичене 3 грецької (Етимологічний словник 6: 209); дружба (мн. - дружбове)- весільний розпорядник, пор.: «Чом тот дружба коня нема? Бо го осідлати не зна. Осідлайме ми му кота, най си сяде на не з плота. Чом тот дружба дружки не ма, бо з ньом танцювати не зна» (Українські народні пісні 34), «А як приде пан молодий з дружбою, возме тебе за рученьку з собою» (Українські народні пісні 41), «Iди, дружбо, до комори, прось родину до покори» (Українські народні пісні 53), «Ей свашка то я, свашка, ей, юж лем пресващила, ей, остатню корову ей, з дружбами пропила» (Українські народні пісні с. 58), «А дружбове посмутніли, хочеся їм спати; Хто же буде за тя, дружбо, весіля тримати?» (Українські народні пісні 67) продовження псл. *drugъ «товариш, приятель» (Етимологічний словник 2: 134); е) назви осіб за внутрішніми ознаками: галган - нероба, ледар, гультяй, пор.: «Ти ту пиєш одрана, а я працюю сама, на тоти бідни сироти, на тя галгана» (Українські народні пісні 213) - запозичення $з$ польської мови; п. gałgan, як і ч. слц. gálgan «тс.», походить від нвн. Gálgen «шибениця», вживаного як скорочення замість Gálgenstrick «розбишака», Gálgenvogel «тс.» (Етимологічний словник 1: 459).

Із назв страв та напоїв засвідчено номени мериндя - харч на дорогу, пор.: «На поле вигнали, меринді не дали, не лій, дойжик, не лій, бо ти не казали» (Українські народні пісні. 203) - запозичення з молдавської і румунської мов; молд. мери́нде (мериндэ) «харчі, провізія», рум. merínde «тс.» походять від лат. merenda «підвечірок», пов'язаного 3 mereo «заробляю, здобуваю; заслуговую» (Етимологічний словник 3: 442); вар кількість, одержана з одноразового варіння; розсіл з квашеної капусти; стеранка - затірка, пор.: «А за той третьой циганки нема на варі стеранки» (Українські народні пісні 217) - пов'язане з псл. variti (Етимологічний словник 1:332); періжки- вареники, пор.: «За тамтой першой небіжки били на маслі періжки» (Українські народні пісні 216) продовжує псл. pirogъ, утворене від pirъ «бенкет» за допомогою суфікса -ogъ (як р. тво́ро́z) (Етимологічний словник 4: 373); палюнечка - горілка, пор.: «Їдеме, їдеме і піском, і медом, ачей достанеме палюнечки з медом» (Українські народні пісні 37) - пор. псл. paliti, пов'язане чергуванням голосних з polěti «горіти; палати», *polmen- «полум'я» (Етимологічний словник 4: 266). Спорідненою вважаємо групу назв посуду для споживання, зберігання їжі та напоїв: погар - кубок, келих, пор.: «А взяла го она, взяла до комори, до свойой, наляла мі погар вина до рученьки, до його» (Українські народні пісні 118), "Дочка в корчмі служила, погар вина вточила, погар вина вточила і тяженько здихала» (Українські народні пісні 162), «Як єм пришов до Берліна, випив єм си погар вина, погар вина крайового, аж мі серце похололо» (Українські народні пісні 280), пор. літ. Погар - що-небудь горіле; залишки чогось горілого; місце, де була пожежа; згарище (Словник 6: 705) - запозичене з угорської мови (можливо, через словацьке 
посередництво) (Етимологічний словник 4: 473); танір - талірка, пор.: «Тримаш горці під лавом, заросли ти муравом, а таніри під столом, заросли ти барлогом» (Українські народні пісні 136) - запозичення 3 угорської мови; уг. tányér «тарілка» розвинулося зі ст. tálnyér «тс.», що походить від іт. tagliere «дошка для різання м'яса» (Етимологічний словник 5: 514); фляшка - пляшка, пор.: «Ей, свашка то я, свашка, ей, премилена свашка, ей, кеби мі стояла, ей перед гамбом фбляшка» (Українські народні nicнi 58) - фонетичний варіант давнішого фляжка, запозиченого через посередництво польської мови 3 німецької; н. Flasche «пляшка» < герм. flaska «тс.» пов'язане з flechten «плести», яке зіставляється 3 псл. plesti (Етимологічний словник 6: 113); антал - бочка на вино або пиво ємкістю 100 літрів, пор.: «А я маю анталочок пива, скупаме ми на тій горі сина» (Українські народні пісні 154) - запозичення з угорської мови; походження уг. antalag не з'ясоване (Етимологічний словник 1: 75).

Добре представлена лексико-тематична група назв одягу та взуття: холоші - зимові штани, пор.: «Як ся свашка напила, то чепчиско стратила, а староста холоші, холоші, бо то било розкошні, розкошні» (Українські народні nicні 54) - продовжує псл. *хоlša «холоша», букв. «та, що облягає», пов'язане з псл. xoliti «чистити», укр. холи́ти; у польській мові [chołosznie], як свідчить повноголосся, запозичене з української (Етимологічний словник 6: 197); чуга - вид верхнього одягу з довгим коміром у галицьких лемків, пошитого з суцільних шматків доморобної тканини, пор.: «Мадяр, мадяр, тримай добре ей, аж ся на ти чуга подре, ей, єдна подре, друга буде, ой, мадяр, мадяр, тримай добре!» (Украӥнські народні пісні 61), «Ішов циган до леса, до леса, лем чуганьком потряса, потряса, вшитки дівки на нього, на нього, же чуганька не його, не його» (Украӥнські народні пісні 307-308) запозичення з угорської мови; уг. csuha «одяг, убрання (як правило, 3 сукна); ряса, кожух; біла груба опанча», найвірогідніше, є безпосереднім запозиченням 3 перської мови, прониклим до Угорщини ще до ії турецького завоювання (пор. перс. с̌иха «одяг, витканий із вовни») (Етимологічний словник 6: 350); кошеля - чоловіча сорочка, пор.: «Бо Яничек нич не робит, лем все пиє, красьні ходит, кошелю ма з павутини, пірко носит з буковини» (Українські народні пісні 145), «Кошеля тоненька, шила єй миленька, під бучком, під грабом зеленим гадвабом» (Українські народні пісні 175) - загальнослов'янське запозичення з латинської мови (Етимологічний словник 3: 70); керпец - постоли; взуття, зроблене з одного шматка шкіри, пор.: «Мислиш ти шугаю, же я тя любую, а я твою любов до керпия обую. До керпия обую, ногами потопчу, жеби люде знали, же я тя не хочу» (Українські народні пісні 172) - очевидно, запозичення зі словацької мови; слц. krрес «постіл», як і ч. ст. і діал. krpec «тс.» споріднене з п. [karple] «примітивне пристосування для ходіння по снігу і болоту», [karpie] «ходаки, черевики 3 дерев'яною підошвою i шкіряним верхом» (Етимологічний словник 2: 425); ногавищи - штани, пор.: «Такий ся мі залицяв, што ногавич пожичав, не піду я за нього, ногавиці не його» 
(Українські народні пісні 223) - споріднене з псл. поgа (Етимологічний словник 4: 108); загортка - піджак; теплий верхній одяг, пор.: «На поле вигнали, загортки не дали, не лій, дойжик, не лій, бо ти не казали» (Українські народні пісні 204) - споріднене з псл. ${ }^{*} g^{\mathrm{b}}$ rtati, ${ }^{*} g^{\mathrm{b}} \mathrm{rtnoti}$ (Етимологічний словник 1:573); ціжми- угорські шнуровані черевики; плитке взуття, пор.: «Цижми ся мі здерли, лащки з мя спадали, хтовди мя англики до роботи взяли» (Українські народні пісні 276) - запозичення 3 польської мови; п. ciżma (одн.) «вид шнурованого черевика» походить від уг. сzіzта «чобіт», до якого зводиться також укр. чи́жми (Етимологічний словник 6: 257).

Ботанічну лексику репрезентовано назвами: шівета - вид злакової трави, пор.: «Там на горі шівета, шівета, пасло дівча ягнята, ягнята» (Українські народні пісні 79); терки - плоди терну, пор.: «Зродилися терки за горами, підеме ми на ні з кошиками, будеме торгати, будеме ламати $з$ конарями» (Українські народні пісні 88); команиця - вид конюшиної трави, пор.: «Беру лен, беру лен сама команичка, воз мене, шугаю, хоц я невеличка» (Українські народні пісні 90) - продовжує псл. komonika / komonica «конюшина; буркун; фіалка; шавлія; полин», найвірогідніше похідне від komonjь «кінь»; назва зумовлена тим, що більшість 3 цих рослин $\epsilon$ цінним кормом для коней, а деякі вживаються як ліки для них (Етимологічний словник 2: 529); чатина - очерет, пор.: «А як ми ся побереме, на тій горі жиц будеме, там си хижу збудуєме, чатином єй обложиме» (Українські народні пісні 146), «Мам я косу, косічку, мам я косу тупу, она мі покосит, бо мусит чатиноньку суху» (Українські народні пісні 206); конар - гілляка, пор.: «Широки конари в тій яблони, повідж мі, дівчатко, што тя болит?» (Українські народні пісні 127), «Зродилися терки за горами, підеме ми на ні з кошиками, будеме торгати, будеме ламати з конарями» (Українські

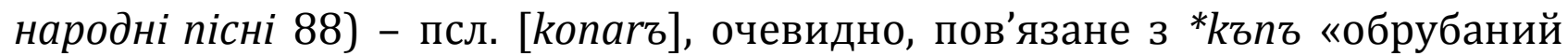
стовбур дерева» (п. kien «тс.») (Етимологічний словник 2: 546); карпіль (мн. карпелі) - ріпа, бруква, пор.: «Ой чом свашки не співают, ой бо рідки зуби мают. Треба карпіль вистругати, свашкам зуби повставляти» (Українські народні пісні 34-35), «А пониже села там карпелі сіют, іщи я маленька, юж ся до мя сміют. А пониже села там карпелі садят, іщи я маленька, юж ся на мі вадят» (Українські народні пісні 170) - запозичення з польської мови; п. karpiel «капуста городня, Brassica oleracea L.» загальноприйнятої етимології не має (Етимологічний словник 2: 395).

До репертуару мовних одиниць на позначення тварин, птахів увійшли лексеми гавран - ворон, пор.: «А і я би купила (очі) свому фраїрови, жеби ся му чорніли, яко гавранови» (Українські народні пісні 92) запозичення з чеської або словацької мови; ч. слц. havran «ворон» $є$ прямим відповідником до укр. гайворон (Етимологічний словник 1: 447); уці - вівці, пор.: «На зеленій та і луці пасло дівча та і уці» (Українські народні пісні 147) результат видозміни форми увия, що є фонетичним варіантом слова вівия (Етимологічний словник 6: 56); когут - півень, пор.: «Серед ночи опівночи 
когути запіли, пришов Аким до Марусі, люде не виділи» (Українські народні пісні 162), «Богатшая сестра когута привезла, а тая біднійша барана привела» (Українські народні пісні 212) - результат спільної для частини східних і західних слов'янських мов видозміни псл. *kokotz «півень» (Етимологічний словник 2: 489); кавка - галка, пор.: «За богацким сином йдут попи з дяками, а за сиротином - ворони з кавками» (Українські народні пісні 261) - пор. лит. kóva «галка», kóvas «тс.» (Етимологічний словник 2: 333); кляча- кобила, пор.: «Я на бабці нич не страчу, бабцю продам, куплю клячу. Кляча здохне, - шкіра буде, а за шкіру жінка буде» (Українські народні пісні 303) - споріднене з псл. *klękja «ломака, колодка, ковінька», пов'язаним із *klęk- «згинати, ламати»; значення «шкапа» в ряді слов'янських утворень виникло на основі «ломака, ковінька», можливо, за незграбну ходу тварини (пор. укр. кляпа «стара корова») (Етимологічний словник 2: 471).

У межах лексико-семантичної групи апелятивних назв географічних об'єктів виділяємо номени: варош - місто, пор.: «Дуй, вітре, варошом, гей, дуй, вітре, варошом за моїм розкошом» (Українські народні пісні 109) запозичення 3 угорської мови; уг. város «місто» $\epsilon$ похідним від vár «фортеця», що зводиться до дперс. сперс. vār «стіна; будова», дперс. vāra «укріплення; захист» (Етимологічний словник 1: 333); валав - село, пор.: «Гей, буду їх варила в солодкім молоці, буду чарувала, гей, буду чарувала по валаві хлопців» (Українські народні пісні 111), «Недалеко, недалеко, лем три милі з валава, верни, милий квітку білий, переночуй до рана» (Українські народні пісні 118), «В зеленім гаю древко рубают, аж до валаву тріски падают» (Українські народні пісні 183).

Поодинокі лексичні діалектизми - це назви споруд та будівель: колиба - житло чабанів і лісорубів, пор.: «Добрі тому Пан-Біг дає, што на горі кошар має, а під гором колибечку, серед села фраӥречку» (Українські народні пісні 207) - мандрівне пастуше слово; для української і західнослов'янських мов імовірне румунське посередництво; рум. colíbă «халупка», як і уг. kaliba «курінь, примітивна хатинка» запозичене від південних слов'ян, до яких, очевидно, прийшло 3 грецької мови (Етимологічний словник 2: 510); турма - вежа, башта, пор.: «На високій турмі два голуби сідат, люде їм завидят, же ся ради видят» (Українські народні пісні 155), пор. діал. турма- отара; зграя птахів (Словник 10: 328).

Багатством і різноманітністю діалектизмів позначена тематична група побутової лексики: газдівка - господарство, пор.: «Беру собі таку, што любит горівку, ой злі, недобрі, проп'є мі газдівку» (Українські народні пісні 35); піпка - люлька, пор.: «Хоц би-м найшов шиту піпку, та не зроблю $з$ баби дівку» (Українські народні пісні 44) - запозичення з романських мов, пор. фр. ріре «велика бочка; люлька; розривний снаряд» (Етимологічний словник 4: 411); клинец, клиночок - забитий у стіну кілочок для вішання чого-небудь, пор.: «Юж лем свою волю на клинещ повісив. На клинещ, на клинец, аж на самий сподок, жеби люде знали, же я не паробок» (Українські 
народні пісні 47), «Виберай, мамичко, зо стіни клиночок, де Ганця вішала зелений віночок» (Українські народні пісні 49) - продовжує псл. klinъ або *kъlinъ, пов'язане 3 *kolti «колоти» (Етимологічний словник 2: 460); ладаскриня з плоским покриттям (віком) для святкового жіночого одягу, пор.: «Ей ци то я, мамичко, не ваша дітина, ей, же сте мі наклали до перини сіна? Ей, до перини сіна, до лади каміня, ей, мамцьо моя, мамцьо, не ваша-м дітина?» (Українські народні пісні 50), «Взяв ти зо мном перину писану, взяв ти зо мном ладу малювану» (Украӥнські народні пісні 220) - через посередництво польської і, можливо, молдавської мов (молд. ладэ через уг. láda) запозичено з німецької; н. Láde «рундук, скриня, шухляда» пов'язане 3 laden «вантажити» (Етимологічний словник 3: 181); сусік - засік, пор.:«Іщи овес в сусіку, в сусіку, што на твою музику, музику» (Українські народні nісні 56) - продовжує псл. sоsе̌kъ (Етимологічний словник 5: 482); заграда клумба, пор.: «Ей бо в заграді ружу, ей сама я садила, ой а тебе мій мужу, ей од Бога-м просила» (Українські народні пісні 57-58); студня, студенечка криниця без зрубу, пор.: «Гей, а яка то добра, ей тота фраӥречка, гей што мі повідала, же єст там студенечка» (Українські народні пісні 60), «У нашого кума на оборі студня, будеме си пили завтра до полудня» (Українські народні пісні 73), «На висівским поли студенечка стоїт, хто коло нєй іде та коники поїт» (Українські народні пісні 174), «Розмариї напасуться, зимной води напиються, зимной води і ледовой зо студенки качмарйовой» (Українські народні nісні 195) - пор. псл. studz (studa) «прохолода, свіжість, холод, мороз», studiti «охолоджувати, прохолоджувати» (Етимологічний словник 5: 457); заглавок - подушка, пор.: «Боже, Боже, який то жаль, ей як попатрю, де я лежав, ей, як попатрю на ту лавку, ой де я лежав на заглавку» (Українські народні пісні 61) - полонізм; фіра, фура віз, підвода, пор.: «Не піду до лєса без сокири, што би я там робив без свой милой, я нарубам на фуру, моя мила на другу гей, гей, гей, гей яворини» (Українські народні пісні 95), «По богатшу сестру тра фбіру післати, а по ту біднійшу лиш переказати» (Українські народні пісні 212) - фонетичний варіант запозиченого з німецької мови слова фура (хура) (н. Fuhre «віз, підвода»), зумовлений, можливо, єврейським посередництвом (Етимологічний словник 6: 102); капустиско - місце, де росла капуста, пор.: «Пасла коні на вигоні, на вигоні і на капустиску» (Українські народні пісні 101); барлога - бруд у хаті та на ліжку; бідна нужденна постіль на ліжку, пор.: «Тримаш горці під лавом, заросли ти муравом, а таніри під столом, заросли ти барлогом» (Українські народні пісні 136) - пор. п. bardlić «бруднити», лит. burlas «бруд», які зводяться до псл. *bьrlogъ, bьrloga (Етимологічний словник 1: 144); колодка - висячий замок, пор.: «Татарка, татарка, зелена татарка, юж ся наша любов на колодку замкла» (Українські народні пісні 173) - очевидно, результат семантичного розвитку слова колодка (мала колода) у значенні «засув», на який могло вплинути інше значення слова «дерев'яні кайдани, що одягалися на ноги», оскільки первісно висячий замок так само складався з двох частин; може 
бути також калькою п. kłódka (Етимологічний словник 2: 518); облачок вікно, пор.: «А в облачку дверка мала, в вишневім садку ночувала» (Українські народні пісні 227) - очевидно, запозичення з угорської мови (уг. ablak) (Етимологічний словник 4: 135); стівка - купюра номіналом 100, пор.: «Ой купуй, жено, купуй, лем кед маш зач купувац, іде там ті стівка, можеш єй скельтуваџ» (Українські народні пісні 278); пильник - напилок, пор.: «Як я ішов горі селом, нашов я там пильник, сходжайтеся, дівчатонька, бо я ворожильник» (Українські народні пісні 290); пискавка сопілка, пор.: «Мав я пискавочку на дванайцят дзюрок, не хтіла ми пискац до богацких дівок» (Українські народні пісні 296) - споріднене з псл. piskъ, piskati, *pisčati < *piskěti (Етимологічний словник 4: 376); трам - колода, балка, пор.: «Дівча, дівча, рушай собом, бо гуляти тяжко з тобом. Волів би я трам тягати, як з тобою танцювати. Трам потягну та й си стану, а з тобом ся не розстану» (Українські народні пісні 299) - запозичення 3 німецької мови (нвн. tra(h)m «балка») (Етимологічний словник 5: 617).

Використано окремі лексеми на позначення військовиків, а також реалій військового життя: жовнір - солдат, пор.: «Чом дуб не зелений, - бо го туча збила, жовнір невеселий, - доля нещаслива» (Українські народні пісні 263) - запозичення з польської мови; п. żołnierz < żołdnierz, як і ч. žoldnéŕ, слц. žoldniér, походить від свн. soldenære «найманець, найманий солдат», яке зводиться до фр. ст. solde «плата» (від назви монети, що походить від лат. (nummus) solidus «тверда (монета)») (Етимологічний словник 2: 202); таністра - військовий рюкзак, пор.: «Одробина місця, під главом таністра - таку постіль мам» (Украӥнські народні пісні 262) - очевидно, запозичення з угорської мови (уг. ст. tanyisztra «торба, сумка») (Етимологічний словник 5: 514); касарня - казарма, пор.: «Посіяла, заграбала, біла рута зишла, чого же ти, моя мила, до касарні пришла?» (Українські народні пісні 264) - запозичення з польської мови (п. kasarnia) (Етимологічний словник 2: 398); канона - гармата, пор.: «На небі звіздочки, то мої дочки, ей а куля із канона, то єст моя жена» (Українські народні nicнi 268) - запозичено з французької; пор. фр. canon «гармата», іт. сапnоne «тс.; широка труба» (Етимологічний словник 2: 365); гвер - рушниця, пор.: «3 правой ручки кров ся ліє, а на правой гвер тримає» (Українські народні nicнi 248) - запозичення 3 німецької мови; нвн. Gewéhr «рушниця» пов'язане з двн. werian «захищати, обороняти», спорідненим з гот. warjan «перешкоджати», псл. vorъ «огорожа, паркан», укр. [вір] «жердяна огорожа» (Етимологічний словник 1: 486); камаратя - товариші, пор.: «Камаратя мої на тім чистім полі з гверів стріляют» (Українські народні nicнi 262) - запозичене через посередництво німецької мови (нім. Kamerad, ст. Kamrad, Kamarad) 3 французької; фр. camarade походить від ісп. camarada «товариш», пов'язаного з camara «кімната (кімната в казармі)», що зводиться до лат. сатеra «тс.» (Етимологічний словник 2: 360); кабат солдатська куртка; пальто, пор.: «Єдно в кабатику - на службину, і друге в сурдутку - на службину» (Українські народні пісні 230) - запозичене 3 
перської мови через посередництво угорської та польської мов (Етимологічний словник 2: 331).

Поодинокими вживаннями представлено ритуально-обрядову лексику: собітка - вогнище, яке запалюють в день Івана Купала; народне гуляння в (день) вечір перед святом Івана, коли запалюють вогнище, молодь перескакує через вогні, танцює і співає навколо них, пор.: «Ішли дівки на собітку, нашли собі чорну кітку» (Українські народні пісні 25), «Ой на Яна на Янонька горіла нам собітонька, як горіла, так палала, аж ся челяд чудувала» (Українські народні пісні 25); темет - цвинтар, пор.: «Долов теметовом бистра вода біжит, юж наша мамичка в чорній землі лежит» (Українські народні nісні 231) - запозичення з угорської мови; уг. temeto «кладовище» $\epsilon$ похідним від дієслова temet «ховати» (Етимологічний словник 5: 542).

Розмаїтим виявився перелік ад'єктивів: шварний - вродливий, пор.: «Прийшов би я до вас каждий вечір, жеби сте мі дали, што би я хтів: на мисочку лену і шварну Олену, то би я хтів» (Українські народні пісні 88) запозичення з польської або словацької мови, пор. пол. szwarny, swarny, świarny, слц. švárny «стрункий, гарний» (Етимологічний словник 6: 395);


де я свої очі діла, же я за тя пішла» (Українські народні пісні 309) запозичення $з$ німецької мови; н. frisch «свіжий, бадьорий» споріднене 3 англ. fresh (Етимологічний словник 6: 395); худобний - бідний, пор.: «Беру си худобну, што не ма родини, ой злі, недобрі, не буде гостини» (Українські народні пісні 35); «Як єм си помисьлів о єдній худобній, то мі запискала на дзюрці доєдній» (Українські народні пісні 296), пор. первісне *худорідний складне слово, утворене 3 основ синонімічних прикметників (Етимологічний словник 6: 220); напасний - нав'язливий, пор.: «Ид же од мя, дівчино напасна, не моя то дітинонька власна. Не піду $я$, хоц я $i$ напасна, бо то твоя дітинонька власна» (Українські народні пісні 154) пор. псл. napastь < napadti (Етимологічний словник 4: 38); вандрівниймандрівний, пор.: «Не вір же мі, моя мила, не вір же мі, моя мила, бо я хлопец, бо я хлопец вандрівний» (Українські народні пісні 306) запозичення 3 німецької мови, пор. н. wandern «бродити, блукати, мандрувати», wandeln «блукати, прогулюватися» (Етимологічний словник 3: 380).

У досліджуваних фольклорних текстах широко вживана дієслівна лексика: газдувати - господарювати, пор.: «Дівчину-м си знайшов, би мя любувала, а жінку не можу, аби газдувала» (Українські народні пісні 81), «Газдую, газдую, юж ліпше не можу, тебе з Гамерики дочекацся не можу» (Українські народні nicні 277) - запозичення з угорської мови; уг. gazda «господар», у свою чергу, походить із слов'янських мов (< слов. gospoda) (Етимологічний словник 1: 451); дуркати - гримати, стукати, пор.: «Їдеме, їдеме, де дві свічки горят, будеме дуркати, ачей нам отворят» (Українські народні пісні 38) - звуконаслідувальне утворення, паралельне до ту́рк(im), 
ту́ркати «стукати, торохкотіти»; можливо, поширилося під впливом словацької мови, пор. п. [durkać] «вдаряти, стукати» (про дощ), [durknq̨ć] «тс.», слц. [durk] «шум, гуркіт» (Етимологічний словник 2: 147); вандрувати, вандрувац - мандрувати, пор.: «Ей, вандруючи, ніжки болять» (Українські народні пісні 61); «Я го виперу, я го висушу, гой-я, гой-я, я го висушу, з вами, воячки, вандрувац мушу» (Українські народні пісні 186) - запозичення 3 німецької мови, пор. н. wandern «бродити, блукати, мандрувати», wandeln «блукати, прогулюватися» (Етимологічний словник 3: 380); банувати сумувати, пор.: «А серденько моє, чом мя поболюєш? Чом ти мі не повіш, за ким так бануєш?» (Українські народні пісні 82), «Баную, баную, буду банувати, буду я за тобом два рочки чекати» (Українські народні пісні 101) запозичення з угорської мови; уг. bán «шкодувати, каятись», bánat «сум, туга, горе» етимологічно неясні (Етимологічний словник 1: 135); кукати кувати, пор.: «Зозуленька кукат, моє серце стукат, зозуленька в гаю, моє серце в жалю» (Українські народні пісні 223) - полонізм, пор. п. kukać (Етимологічний словник 3: 121); пукати - стукати, пор.: «Не пукай, не дуркай, бо ти не отворю, бо я о такого фреїра не стою» (Українські народні nicнi 300) - продовжує псл. pqkati, pqk(nq)ti «тріскатися», очевидно, звуконаслідувального походження, паралельне до *poukati «стукати, тріскати» (Етимологічний словник 4: 630); петлювати - отримувати пшеничне борошно тонкого помолу, мелючи на пителі, пор.: «Буде з мя добра газдиня, бо рада ношу до млина, рада пшеничечку петлюю, рада пероги готую» (Українські народні пісні 170), пор. діал. петлюватипетляти (Словник 6:344) - запозичення 3 польської мови (п. pytel «пристрій для просіювання борошна; мішок; млин») (Етимологічний словник 4: 379); заваровувати - боронити, оберігати, пор.: «Заваруй мя, Боже, од злого, од злого, од води великой, од мужа бридкого, бридкого» (Українські народні пісні 179); варувати - берегти, пор.: «Од води великой варувац, варувач ся буду, за бридкого піду, а гардих любувати буду» (Українські народні пісні 180) - очевидно, спільнослов'янське запозичення 3 давньоверхньонімецької мови (двн. (bi) waron «зберігати, берегти», нвн. wáhren «тс.») (Етимологічний словник 1: 334); пораяти - порадити, пор.: «Пораїли, пораїли дубового сала, а як він єй висмарував, аж скіра одстала» (Українські народні пісні 304) - зворотне дієслівне утворення від іменної форми ра́йца, яка виникла на польському грунті 3 давнішого *rad(ь)ca, похідного від $\operatorname{rad}(z) i c ́$ «радити» (Етимологічний словник 5: 35); стрікатипоколювати, пор.: «Як зачали оченька стрікати, та й зачали за мном зараз дівчата плакати» (Українські народні пісні 291) - продовжує псл. strekati «колоти» (Етимологічний словник 5: 442); трафляти - влучати, пор.: «Воюю, воюю за свого милого, жеби не трафбла кулечка до нього» (Українські народні пісні 260) - через польське посередництво запозичено 3 німецької мови, пор. нвн. treffen «потрапляти, влучати; зустрічати» (Етимологічний словник 5: 622); скельтувати - розтратитись, пор.: «Ой купуй, жено, купуй, лем кед маш зач купувац, іде там ті стівка, можеш єй 
скельтувац» (Українські народні пісні 278) - запозичення з угорської мови; уг. költeni «витрачати; споживати» (звідки költség «витрати») є каузативом від дієслова kel «вставати, виникати, рости, зникати» (Етимологічний словник 2: 421); зуяти - схопити, пор.: «Жалі мої, жалі, як-сте мя зуяли, не з єдного боку, але з каждой страни» (Українські народні пісні 86) - зуяти топтати, псувати (Етимологічний словник 2: 284).

Мікросистему адвербіальних одиниць формують діалектизми фришно - скоро, пор.: «А я го не вкрала, оно само пришло, а я го заперла до стаєнки фришно» (Українські народні пісні 71) - запозичення з німецької мови; н. frisch «свіжий, бадьорий» споріднене з англ. fresh (Етимологічний словник 6: 395); помалючки - повільно, помаленьку, пор.: «Посіяли його (льон) миленького ручки, я го буду брати стиха, помалючки» (Украӥнські народні пісні 90); зас - знову, пор.: «А хоц би погородив, од землі аж до неба, а я до ней зас піду, ей як мі буде треба» (Українські народні пісні 97) запозичення з польської або словацької мови (Етимологічний словник 2: 239); доправди - справді, пор.: «Любив мене шувний Івасенько, але не доправди» (Українські народні пісні 164); преокрутні - дуже сильно, пор.: «Лем ся преокрутні злих язиків бою. Бо тоти язики, гірше ніж од меча» (Українські народні пісні 172); домню - додому, пор.: «Тій богатшій сестрі дают їсти-пити, а тії біднійшій кажуть домню іти» (Українські народні пісні 212), «Пришла она домню, сіла си на лави» (Українські народні пісні 212); взаран - завтра, пор.: «Не пию палюнку, лем арак, лем арак, не підуя домім, аж взаран, аж взаран» (Українські народні пісні 227).

3-поміж службових частин мови виділимо лексеми през - через, пор.: «Як я ішов през тот ліс, през тот ліс калиновий, станув я там на камін, камін мармуровий» (Українські народні пісні 196-197) - запозичення 3 церковнослов'янської мови, можливо, підтримуване польським впливом (п. przez) (Етимологічний словник 4: 561); г - прийменник (префікс) y, в, пор.: «Кілько в решеті тих дірок, тілько г' Висові крас дівок» (Українські народні пісні 19), “ $\Gamma^{\prime}$ Васильвім дворі проквитат туліпан, Василь ся виберат, як дакий капітан» (Українські народні пісні. 36), «Як я ишов вчера г'вечір з грабаня, надибав я шварне дівча зо спаня» (Українські народні пісні 120), «А кажда пришла г'віночку, лем та рихтарьова в чепочку» (Українські народні пісні 144), “А за той другой небоги плавали г'воді, г'воді плавали, плавали г'воді стоноги» (Українські народні пісні 218); лем - тільки, лише, пор.: «Ніж ся хлопці посходили, дівки кітку розхватили. Не солену, не мащену, лем попелом потрясену. I попелу дост не мали, лем од хлопців пожичали» (Українські народні пісні 26), «Не підуя до лєса з кониками, бо би мене гайдуци полапали, лем я піду на лучку возьму дівча на ручку» (Українські народні пісні 96) - результат видозміни форми [лен] «тільки, лише» (Етимологічний словник 3: 219); ци - чи, пор.: «Боже, Боже, што ся стало, же на яблони яблок мало? Ци не било, ци упали, ой ци їх хлопці обірвали?» (Українські народні пісні 62) - пов'язане з др. цђ «хоч, проте», стсл. ць «але, також, адже; хоч, проте; якби, хіба, тільки», для яких 


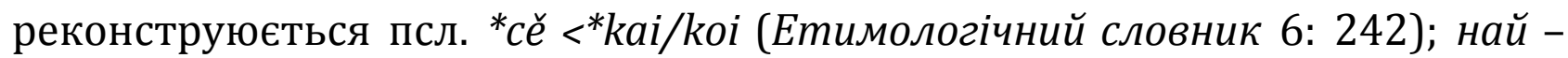
хай, пор.: «Вертай, вертай, козаченьку, - вмирає матуся. Най вмирає, най конає, я вже не вернуся» (Українські народні пісні 151), «Ой сину мій, сину, вернися додому, най я ти зачешу головоньку твою» (Украӥнські народні nicнi 259) - можливо, вже псл. пајь «нехай, облиш, дай змогу» як результат стягнення виразу пехајі «не чіпай» (Етимологічний словник 4: 30); покля поки, доки, пор.: «Нич ти, синочку, не буде, лем покля сонще не зайде» (Українські народні пісні 140); «Гей юж ми одталь не підеме, гей, гей, покля ми єй не вип'єме» (Українські народні пісні 176) - продовжує псл. *po kolě (*pokoli) з основним просторовим і похідним часовим значенням «до якого місця; до яких пір, поки» (Етимологічний словник 4: 482).

Поодинокими номенами представлено інші семантико-тематичні групи діалектизмів: карта - лист; офіційний документ, пор.: «Пришла карта з Сянока, штоби дали вояка, гей, ріттом, ріттом, дана, штоби дали вояка» (Українські народні пісні 140), «Пришла мі карта до войска іти, плаче миленька, плаче серденько» (Українські народні пісні 251) - через польську або німецьку мову запозичено з французької або італійської (фр. carte, іт. carta «папір; карта; документ») (Етимологічний словник 2: 395); бузя - уста, губи, пор.: «Повіла-с мі два раз, повідж іщи раз, як я до вас г'вечір приду, чи мі бузі даш?» (Українські народні пісні 181) - можливо, давнє звуконаслідувальне утворення від *bu- «цілувати, губа, рот» (з мови дітей) (Етимологічний словник 1: 283).

Висновки та перспективи досліджень. Використання як джерела лінгвальної інформації про говірки Лемківщини місцевих уснопоетичних текстів уповажнює на певні висновки. Фольклорні твори можуть бути прекрасним доповненням чи підтвердженням для діалектологічних спостережень, здійснених на основі інших матеріалів, але лише за умови достовірної фіксації текстів упорядником.

Основу словникового складу лемківських говірок становить загальнонародний український лексичний фонд, з чим погоджується i більшість вчених. Проте для цього говору характерне й велике розмаїття специфічно лемківських діалектизмів. Проаналізований матеріал дозволив виділити понад 10 лексико-семантичних груп. У лексиці лемків наявна значна кількість різних запозичень 3 інших мов, передусім сусідніх польської, словацької та німецької.

Опора на фольклорні тексти, основною умовою фіксації та пізнішого опублікування яких стало точне передання мовних особливостей народних творів із мінімальним або й зовсім відсутнім редакторським втручанням, відкриває широкі перспективи вивчення формальної структури говірок українського діалектного континууму. Подальше вивчення цієї проблеми вбачаємо в здійсненні аналізу диференційних ознак фонетичного та граматичного рівнів лемківських говірок на матеріалі місцевих уснопоетичних текстів. 


\section{Список використаних джерел}

Етимологічний словник української мови, за ред. О. С. Мельничука. В 7 т. Київ: Наукова думка, 1982-2012.

Словник української мови, за ред. І. К. Білодіда. В 11 т. Київ: Наукова думка, 1970-1980. Українські народні пісні з Лемківщини. Горлиці, 1997-2002.

\section{Sources}

Etymolohichnyi slovnyk ukrainskoi movy, edited by O. S. Melnychuk. 7 vols. Kyiv: Naukova dumka, 1982-2012.

Slovnyk ukrainskoi movy, edited by I. K. Bilodid. 11 vols. Kyiv: Naukova dumka, 1970-1980.

Ukrainski narodni pisni z Lemkivshchyny. Horlytsi, 1997-2002.

\section{Список використаної літератури}

Верхратський, Іван. Про говор галицких Лемків. Львів, 1902.

Жилко, Федот. Говори української мови. Київ, 1958.

Залеський, Антон. «Найбільш західний український говір». Культура слова, вип. 33, 1987, с. 68-71.

Наконечний, Володимир. Лемки в ХХ столітmі: життя на етнічних землях та в нових геополітичних умовах. Автореф. дис. ... канд. істор. наук: 09.00.12. Київ, 2008.

Орловська Б.-А. «Асиміляція чи адаптація лемків на західних землях Польщі». Карпатський край, № 1 (3), 2013, с. 5-12.

Пиртей, П. Короткий словник лемківських говірок. Івано-Франківськ: Сіверсія МВ, 2004.

Угода між Урядом Української Радянської Соціалістичної Республіки і Польським Комітетом Національного визволення про евакуацію українського населення 3 території Польщі і польських громадян з території УРСР (від 09.09.1944). URL: http://zakon3.rada.gov.ua/laws/show/616_065

Український інститут національної пам'яті. URL: http://www.memory.gov.ua/

Халюк, Леся. «Акція „Вісла” 1947 року в усних оповідях українців-переселенців: історія досліджень і тематика». Народна творчість та етнологія, № 3, 2018, с. 71-8.

Studia methodologica, вип. 27, 2009.

Z łemkowskiej skrzyni. W 2 cz. Lemko-Tower, 2004.

\section{References}

Verkhratskyi, Ivan. Pro hovor halytskykh Lemkiv. Lviv, 1902.

Zhylko, Fedot. Hovory ukrainskoi movy. Kyiv, 1958.

Zaleskyi, Anton. "Naibilsh zakhidnyi ukrainskyi hovir". Kultura slova, iss. 33, 1987, pp. 68-71.

Nakonechny, Volodymyr. Lemki in the XX century: life on the ethnic lands and the new geopolitical context. PhD Thesis Abstract. Kyiv, 2008.

Orlowska B.-A. "Assimilation or adaptation of Lemkos in the western Polish". Karpatskyi kray. no 1 (3), 2013, pp. 5-12.

Pyrtei, P. Korotkyi slovnyk lemkivskykh hovirok. Ivano-Frankivsk: Siversiia MV, 2004.

Uhoda mizh Uriadom Ukrainskoi Radianskoi Sotsialistychnoi Respubliky i Polskym Komitetom Natsionalnoho vyzvolennia pro evakuatsiiu ukrainskoho naselennia z terytorii Polshchi i polskykh hromadian $\mathrm{z}$ terytorii URSR (vid 09.09.1944). zakon3.rada.gov.ua/laws/show/616_065

Ukrainskyi instytut natsionalnoi pamiati. www.memory.gov.ua

Khaliuk, Lesia. "The 1947 Operation Vistula in the Light of Oral Narratives of Ukrainian Settlers: A History of Studies and Themes". Folk art and ethnology, no 3, 2018, pp. 71-8.

Studia methodologica, iss. 27, 2009.

Z łemkowskiej skrzyni. W 2 cz. Lemko-Tower, 2004.

Стаття надійшла до редколегії 28.01.2019 